\title{
The character of the Dragon/Serpent in Japanese and Ukrainian fairy tales
}

\author{
N. Naumovska \\ PhD student of Taras Shevchenko National University of Kyiv, Kyiv, Ukraine \\ Corresponding author. E-mail: mipholle777@gmail.com \\ ORCID: 0000-0001-5281-0345
}

Paper received 09.11.19; Accepted for publication 22.11.19.

https://doi.org/10.31174/SEND-Ph2019-212VII63-10

\begin{abstract}
The article is devoted to the analysis of the character of the Dragon/Serpent in Japanese and Ukrainian fairy tales. Its main functions, the role in plots and motifs, teratomorphic and anthropomorphic features are compared. The mythological basis of the character as a participant in the creation of the world and antagonist of the protagonist is outlined. Through comparative analysis is justified, that in Japanese fairy tales, the character of a Dragon/Serpent has the same features as the Ukrainian and Western European tradition, as well as purely national specifics.
\end{abstract}

Keywords: fairy tales, dragon, serpent, character, motif, antagonist, plot.

Introduction. The worldwide character of the Dragon/Serpent is often presented as a villain in the fairy tales of different ethnic groups. The formation of this character took place over a long period. In the beliefs of different ethnic groups, the Dragon/Serpent has a demonic being signs. Foremost, they were presented as guardian spirits of springs, waters, mountains that embody natural disasters. The character of the Dragon is presented in almost all myths about the creation of the world. The sacred texts of ancient nations identify it with the Primal Chaos, which comes into conflict with the Creator of Space. For example, in the cosmogonic Sumero-Akkadian myth «Enuma Elis», the main god of the Babylonian pantheon, Marduk, defeats progenitrix of the gods, the embodiment of the Chaos, the primal ocean, the dragon-like goddess Tiamat, who has the appearance of a monster with crocodile jaws, paws of lizards, eagle claws, the body of a snake and horns of a bull; From her body he creates the earth and forms the life from the dragon's belly [5; P. 329.]. In the West-Semitic mythology, the god of fertility and storm, Baal, has a cosmic battle with the god of the marine element, the master of the sea Yam [10; P. 134]. In the Egyptian mythology, the god of the sun of Ra every night goes down to the underworld and wins, the incarnation of the darkness, the serpent Apepi (Apophis), so that a new day could come. In the Vedic pantheon the king of the king of the highest heaven, god of the thunderstorms Indra defeats the serpent/dragon Vritra [15; P. 63]. The character of the mythological world serpent, the Ouroboros, which embraces the the Earth in a ring by eating its own tail, is one of the first symbols of infinity in the history of mankind [19; P. 27]. Unfortunately, the exact origin of the Ouroboros character, the historical period and a specific culture, can not be established [14]. This symbol of the Ouroboros has many different meanings. The most widespread interpretation describes it as a representation of eternity and infinity, especially life's cycles: the alternation of creation and destruction, life and death, constant rebirth and doom. Symbol of the Ouroboros has a rich history of use in religion, magic, alchemy, mythology and psychology [8; P. 29].

Ancient Vikings called their ships Dragons (drakkars), for them the dragon was a guardian, so they drew its image on the bow of the ships [13; P. 111], [21; Pp. 601605]. In ancient Greek myths, antagonists are often depicted as dragons. For example, a terrible dragon guarded the Golden Fleece in the myth of the Argonauts; the god of war, Ares, summons a huge dragon/serpent that is then killed by Cadmus, the founder of Thebes [26].

Dragons are frequent characters in the legends and legends of Taoism and Buddhism; they play an important role in the mythological systems of the Eastern countries: Japan, China, Vietnam, Indonesia, and others [3]. Dragons are often depicted as winged serpents, such combination of animals represents two worlds: the upper world (birds) and the lower world (serpents). In the Egyptian, Indian, Chinese, and other religions, initially, the gods were represented by various animals; their features have formed the character of a dragon, the body of which consists of different animals body parts. At the same time, in many nations, the depiction of the character of a dragon is closer to the serpent.

In Japanese fairy tales and legends there are mostly dragons, and in Ukrainian fairy tales - serpents. This character is important in the tales of both nations, therefore the research and comparison is informative for understanding the national specificity of folk traditions of Japan and Ukraine.

Analysis of recent research and publications. The history of collecting and researching Japanese fairy tales is extremely long - about 1000 years.

At the beginning of the XI century. A set of Japanese, Indian and Chinese tales «Konjaku Monogatari» (今昔物語) (lit. «Anthology of Tales from the Past») was created (31 vol.). Genre spectrum of this collection is quite wide: it contains Buddhist legends, magic and adventurous fairy tales, short stories, anecdotes. In the XIII century. another similar book appeared: «Uji Shūi Monogatari 《(宇治拾遺物語) (lit. «A Collection of tales from Uji»).

At the beginning of the eighteenth century. The world saw a collection of «Otogi-zōshi» (御伽草子) (lit. «Night Stories»), which included 23 stories, mostly magical and adventurous folktales. In the XIX-XX centuries. collecting and publishing folk tales in Japan has become widespread. In Tokyo in 1958-62 was released 42 volumes of «Nihon No Minwa « («FolkTales of Japan»).

«Father of Japanese Folklore» - Kunio Yanagita (柳田 國男) owns numerous collections of Japanese folk prose (for example, «Tono monogatari») and works on the study of Japanese folklore. He made one of the first classification of Japanese fairy tales. Kunio Yanagita noted 
that by creating his classification he relied on the previous, already existing, developed classification by Aarne and Thompson. However, the scientist pointed out the need to take into account the specific features of the Japanese folktales [33], [24; Pp. 83-115].

The outstanding Japanese folklorist Keigo Seki (関 敬吾), compiler of one of the most famous collections of Japanese fairy tales - «Nihon Mukashibanashi Shūsei» (日本 昔 話 集成) (lit. 《Compilation of Japanese Folktales» - 1957) in 3 volumes, also developed his own classification of genre varieties of folktales and followed the way of life and ritual basis of Japanese folktales. He noted that the fairy tale was told before planting rice or after harvesting in order to receive the affection of the gods of fertility [1; Pp. 272-275]. Thus, the scientist drew attention to the mythological basis of fairy tales.

However, it was not possible to find a study of Japanese folklorists about the character of a Dragon/Serpent in traditional fairy tales.

For a better understanding of the nature of the character of the Dragon/Serpent one should refer to the research on mythology and demonology of Tylor, B.E. [32; Pp. 266-268], Frazer, J.G. [11; Pp. 48-52.]. Serpent as a character of a fairy tale, in particular its genesis, functions, and others are viewed in works of Davidyuk, V. [6], Dunaievska, L. [7], Novikov, M. [25], Propp, V. [27].

In the monograph «Historical roots of a fairy tale», Propp, V. singled out the following types of the character of the Serpent in the Russian fairy tales: Serpentkidnapper; the Serpent which collects the tribute; the Serpent-guardian of the borders; the Serpent - devourer [27; Pp. 216-281]. Novikov, M. added to this category the Serpent-tempter [25] and noticed that the definition of the «Serpent-guardian» is inaccurate, since it is not clear which boundaries it protects. The Serpent, rather, does not protect, but violates the border by being the first to aggressively attack. Dunaievska, L. regards the Dragon/Serpent as a central character of a villain. She links the motif of fighting the Dragon/Serpent with the motif of devouring, which is reflected in the primal initiation ceremony.

However, the comparison of the character of the Dragon/Serpent in Japanese and Ukrainian folk tales has not yet been the subject of scientific researches.

The purpose of the article. To comprehend the main features of the character of the Dragon/Serpent in the Japanese fairy tales; plots, motifs and basic functions associated with it, revealing the mythological origins of its origin in comparison with the Ukrainian fairy tale tradition.

Research methods. The complex nature of the study involves the integration of a number of scientific methods. The article uses the method of system analysis, which allows to systematize the research material accumulated by various branches of humanitarian knowledge of traditional culture. For a deep and comprehensive understanding of the character of the Dragon/Serpent in Japanese and Ukrainian folklore the comparative folkloristic analysis of characters is used. A structuraltypological method is also used to find out the general and specifically national nature of the origin of folklore characters.
Presentation of basic material of the research. The motifs of the struggle of the heroes with evil forces (villains) and the victory of the good side are common fot the fairy tales of ethnic groups (No. 300-303 for the Index of Aarne-Thompson's plots and motifs) [31]. The most numerous group of fairy tales of the «heroic» type in the Ukrainian tradition are fairy tales about the dragon fighters.

Ukrainian folklorist Dunaievska, L. links the motif of fighting the Dragon/Serpent with the motif of devouring, which is reflected in the primal initiation ceremony. The conflict of the protagonist with the serpent-tempter is common for the plots of "getting the wife. Investigating the character of the Dragon/Serpent, Dunaievska, L., emphasizing its anthropomorphical features in the Ukrainian fairy tale tradition, argues with Russian scientist Propp, V. [27], who claimed that the Dragon/Serpent which is always depicted as multi-headed creature, which never uses weapons, does not help itself with his paws or teeth. Dunaievska, L. states that: «In Ukrainian fairy tales, Dragon/Serpent is often depicted in a peasant way of life, and its actions are likened to the actions of an ordinary peasant. Often it has human features» [7; P. 146]. In particular, in the Ukrainian fairy tales «About the hero Bukha Kopytovych», «Chabanets», «Cyrylo Kozhumyaka», and others - the Serpent/Dragon beats the hero with an iron or steel sword, bites him with its teeth, and so on. In addition, in the Ukrainian fairy-tale the Dragon/Serpent has signs of the Middle Ages Knights: it gives the hero the right to start the battle, offers him to hit first and offers him a rest during the battle. Mostly, the Dragon/Serpent acts on its «territory» - between the world of the living and the world of the dead. In addition, the Ukrainian national specificity of the character of the Dragon/Serpent has a contamination with the character of the Chort (Slavic antropomorphic demon), which, on the one hand, confirms the motif of the otherworld, transformed by the national consciousness, and on the other hand, in contrast to the characters of demonology, does not have the spirit of malice and, in some way, is similar to a human.

The texts, that contain the motifs of the fight with the Dragon/Serpent, are mostly related to the heroic fairy tales type both in the Ukrainians and in the Japanese traditions. Unlike the Ukrainian fairy tales, where the villains are mostly anthropomorphic, in Japanese fairy tales the villains are zoomorphic: they have several pairs of eyes that shine with terrible fire, terrible claws and can fly in the air. They are often depicted having different animals' body parts: «It was a terrible dragon. It has a huge horse head on a snake's neck with bull's ears. The waist and the back of the dragon was covered with the blue scales [16; P. 118]. They operate in all «three worlds» of the vertical division, although they live mainly in caves, abyss. They also have the ability to reincarnate and often try to overcome the hero by using tricks. For example, in the fairy tale «Kendzo-winner», a terrible blue dragon turns into a beautiful young female, lures the hero into the cave and during the hero's sleep chains him to the wall [16; P. 114116].

It can be argued that the monsters- villains of Japanese fairy tales, as well as in the Ukrainian fairy tales, where the Dragon/Serpent never initiate a fight with the protagonist and always offer a rest, also partly has «knightly» 
features: although they do not expect the hero to «fight or tolerate» and do not offer rest, but give the hero the opportunity to give up his intention (to kill the Dragon/Serpent) and thus save his own life: «Let's go back home and I will not fight you! - the dragon said - If you do not agree, I will starve you to death» [16; P. 118]; «This stone holds on a hundred ropes. Every second I will cut one rope. If in one hundred seconds you do not consider yourself defeated, the stone will crush your head!» [16; P. 119].

The Dragon/Serpent in Ukrainian fairy tales mostly kidnap young females or require them to be sacrificed to it. As for the Japanese fairy tales, the Dragon/Serpent predominantly acts as mountain or water spirit, guardian of treasures, as in the quoted above «Kendzo-winner,» where the Dragon protects human welfare (wisdom, health, honestly gain wealth, courage, knowledge, and others) hidden in the chest at the top of the Golden Mountain [16; P. 107].

It is worth noting that in Ukrainian fairy tales the Dragon/Serpent is always play the role of an antagonist of the main protagonist. But, in Japanese fairy tales it is possible to find, the typical for the Asian folk traditon, the character of the Dragon God (《龍神》) is portrayed - the sea ruler, the father of the beautiful Otochime, but it is a positive character. For example, in the fairy tale «Father's Wife», the Dragon Lord invites to the underwater kingdom of boy Dosimaru, who saved Otokhim, and gives him three magic pearls, with which Dosimaru cured his father from a fatal illness, began to understand the language of birds and animals, as well as defeated the wicked sorcerer and became rich [17]. In fairy tales with a motif of the fight against evil, the other characters of Japanese demonology often act as antagonists: demons oni, the lake spirit and lord Nushi, and others.

However, in the fairy tale «Kendzo-winner», the enemy of the protagonist is precisely the Dragon. The fisherman Kendzo Shinobu goes to the Golden Mountain to get «human goods» that the monster keeps [16; P. 112]. The Dragon in this fairy tale appears in a zoomorphic form and has the body parts of various animals: the neck of the snake, the horse's head, the bull's ears and horns, the fish blue scales on the back. However, it has the ability to turn itself into a human, this way it turns into a young female lures the hero into the cave and chained him to the wall during his sleep.

Kendo does not win the dragon by himself: it is made by a magician, who previously appeared to the young man in the form of a traveler and pointed the way to the Golden Mountain. The traveler was dressed in red clothes and in his right hand he had a golden sticks, that is, a charming attribute. The battle between the wizard and dragon is a series of metamorphoses: they turn into wolf/tiger, gooseberry/eagle, moth/boar. In the end, the Dragon turnes into a stone and the magician, using a magic wand, transforms it into venomous flies and from the sand with a help of magic he creates a flock of sparrows that caught the insects. The last fly is caught in a web, with a help of which the wizard has tightened the sky. Then the Dragon turns into his real form, falls down and perishes [16; Pp. 122-123].

In Ukrainian fairy tales, as in most Japanese ones, the battle takes place between the main protagonist and vil- lain, so the motif of the battle of this fairy tale is rather rare. However, the motif of metamorphosis in fairy tales of the both nations is common. In the Ukrainian tradition, it is mostly a narrative about the presence of the protagonist in the otherworld with an aim to receive magic knowledge there. They are considered as narratives that describe the processes of initiation: maturation, the transformation of a young man into a husband and marriage. In the Ukrainian fairy tale «Oh», the young man needs to live in the underground world for three years; he learns to turn himself into various animals and objects. Returning home, he turns himself into three animals: hunting dog, falcon and horse. In those transformations his father sells him at the market for a great price. However, the son orders his father in no case to sell a falcon hat, a chain of a hunting dog or a saddle of a horse. In those three objects the hero hides his powers and anyone who gets them can become the owner of him. However the main antagonist, the Oh, becomes a Gypsy with one blind eye (partial blindness of the villain links the character to the otherworld), tricks the main hero's father. Trying to escape from the $\mathrm{Oh}$, the young man turns into the perch $(\mathrm{Oh}-$ into a pike); then the young man turns into the ring and falls into the hands of the princess. When the Oh comes to get him, the princess throws a ring on the ground and turns into seeds. The Oh tries to eat them but from the last seed «the hero turned into a handsome young man and the princess, as she saw him, fells in love at once.» The fairy tale ends with a wedding and a with the Ukrainian traditional final phrase» I was there and drank honey wine...» [12; P. 99].

Back to the analysis of the fairy tale «Kendzo-winner». It is worth noting that the main conflict of this fairy tale is not typical: the protagonist goes on a journey because he whishes «that all the Japanese have wisdom, health, wealth, bravery, knowledge and joy» [16; P. 107]. The fairy-tale has the motif of the «chosenness» of the hero [16; P. 123]. That is why the wizard saves Kendzo, he was convinced of his dignity for this task. Thus, national, patriotic motifs are emerging in this fairy tale, which in general are more characteristic of other genres of folklore (heroic epics, legends, and others).

In Ukrainian faairy tales about heroes with extraordinary powers, the main «villian» is depicted as the Serpent (in anthropomorphic or zoomorphic forms). For example, the White Poganyn (a fairy tale «About The Boy Who Freed his Mother from the Captivity of the Poganyn» [12; Pp. 341-357]. Or the Lucifer (fairy tale «Twenty-Five Brothers») [12; Pp. 268-271] as the leader of the Chorts. It is a later character, which appeared under the influence of Christianity, but has «typical features» of the Serpent.. Sometimes the antagonist of the main character can be depicted as any other frightening monster with the features of the Serpent, but with its own name - for example, Pesyholovets (fairy tale «Silk State) [12; Pp. 308-316], Poganyn (fairy tale «About The Boy Who Freed his Mother from the Captivity of the Poganyn») [12; Pp. 341357] Liktyboroda (fairy tale «Fairy tale about Lugay») [12; Pp. 489-497] and others. It should be noted that in Japanese fairy tales, in most cases, dragons do not have their own names.

In the Ukrainian fairy tales the motive of victory over the Serpent/Dragon is often linked with the motif of «get- 
ting the bride» by the main hero (a captive girl or a Serpent's daughter). But in a majority of the Japanese fairy tales, as Sadokova, A. notes, the, «_It is impossible to detect a «love» line at all». Some «exception» are fairy tales about a "charming wife», but the unearthly beauties of these stories «are called to carry out a miracle on earth and leave their chosen one vague and lonely» [29]. That is, for the fairy tale prose of Japan, the motifs for finding the bride, the fulfillment of the ritual tasks given by the parents of the girl or her own are not generally characteristic - and the marriage of the hero is by no means the goal of Japanese fairy tales, they do not describe the marriage initiation as such. Among the heroic fairy tales of Japan, the fairy tales «Taro the strongest» and «Momotaro» deserves a special attention. it should be noted, that the Ukrainian fairy tales «Pokotygoroshko» («Kotygoroshko») and «Chabanets» have the similar plot.

Like most Ukrainian fairy tales, the main heroes of Japanese fairy tales have a magical birth (origin). For example, the Taro's mother «prayed to the goddess of mercy Canon for hundred days, and the boy was found on the hundred first day. He grows fast as if yeast» [30; P. 316].

The same thing we observe in the Ukrainian fairy tale - Pokotigoroshko's mother saw a pea in a bucket, «... she took and eaten it, and a son was born from that pea. They gave him the name of Pokotigoroshko. He grows not by days but by minutes» [12; P. 20].

Momotaro came out of a peach that his grandfather and grandmother have found, that is why he was named Momotaro («momo» - jap. «Peach»).

In the Ukrainian fairy tale «About the Boy Petro and the Bull» a man with a woman who «lived together and did not have a child for ten years», and «their cow that for ten years could not give a birth to a calf» [12; P. 432]. Their son was born only after a man had excavated the mountain and made the way through it to help people, so he was «paid» for his kindness. He was born in the same day with a bull, who became his loyal companion. A similar motif of birth in one day with the main hero and his charming horse (dog, bull) is common for many Ukrainian fairy tales; in this case, a special relationship is established between the hero and his companion (for example, they may feel each other's death).

A good act of parents as a necessary «requirement» for the birth of a child is a common element of the plot. For example, in the fairy tale «About Sukhenko-the hero»: the monks being thankful for the the King's act to build a bridge through the river, said what must be done for his son to be born: «Bring silk, make a trawl from it, catch epy golden pike in the sea with it, give the golden pike to the queen and she shall eat it/ Only than she will have children» [12; P. 137].

Indeed, the birth of Suchenko was unusual: the cooker and the queen tried the soup made of the magic golden pike and «the dog under the table tried some bones of the fish» - «the cooker had a son, the queen had a son and a dog had a «son» in one day...» [12; P. 37].

Such plots represents the ancient beliefs in animals as a human totemic ancestor.

Both in Japanese and in the Ukrainian fairy tales, the heroes have extraordinary powers, which is followed by the choice of their weapons. For example, Taro from the fairy tale «Taro the strongest»: «... They collected all their money and asked the smith to make an iron rod of three hundred kilograms. The whole village tried to pull it. The boy looked at the stick and smiled, and then grabbed the end and exclaimed: «Eh-e-hr!..» after what immediately turned into the giant» [30; P. 317].

The character of the hero in this fairy tale is complicated: he does not just have supernatural power - his physical appearance is its reflection.

In the Ukrainian fairy tale «A Tale About the Boy Petro and the Bull», the hero Petro has a dream in which someone advises him to make a giant «bulava» (Ukrainian traditional type of mace), otherwise he will not defeat the Serpent: «He went to the blacksmith and made such a mace that

twelve men were taken from the forge» [12; Pp. 308317].

In the fairy tale «Momotaro» the identification of the true strength of the protagonist is preceded by his passivity, «eccentricity», and, accordingly, «distrust of the hero who seems to be hopeless»-Meletinsky, E. distinguishes it as «a common characteristic of many heroes of fairy tales» [23; P. 189]. In fairy tales where there is an aim of the match and marriage of the hero, the initial passivity of the hero, his inability to disagree, as the scientis notes, are opposed to «the activity of miraculous forces» [23; P. 194].

Very often in such fairy tales the hero is depicted as the youngest brother (for example, the Ukrainian fairy tale «Silk State») [12; Pp. 308-316]. But initial demonstration of inaction, he alone performs the task of the king and gets a wife. Most researchers connects such happy ending for the youngest in the family with the phenomenon of a ultimogeniture (a principle of inheritance in which the right of succession belongs to the youngest child) and the later primogeniture (the right of succession belonging to the to the eldest child) which had replaced the ultimogeniture, but in the perspective of the people, the first phenomenon remained «correct», «faithful». That is the reason for the appearance of fairy tales about the violation of the youngest brother's by older brothers (as a phenomenon of primogeniture) and his victory at the end as the establishment of a «fair system».

In the Ukrainian fairy tale "Pokotigoroshko" the birth of the main character, Pokotigoroshko, happens after his brothers and sister's kidnapping by the Serpent. Therefore, the hero's journey is clearly planned: he wants to defeat the Serpent and release his brothers and sister [12; Pp. 19-22].

In the fairy tale «A Tale About the Boy Petro and the Bull» the main character Petro rescues the princess from the Serpent and get married to her [12; P. 433]. The reason for the conflict of Sukhenko and the Serpent (a fairy tale «About Sukhenko-warrior») was his draw with brothers Tsarenko and Kukhovarich to determine the ataman (the main Leader). His released arrow got stuck in the window of the Serpent's house. In the fairy tale, there is also an element of "prior knowledge» of the Serpent and Suchenko about their upcoming meeting and battle: «Stand, horse, do not be stumbled, you badger's wool, do not raise... Somewhere there is a fellow Suchenko, his bones raven will not bring here.» The plot of this fairy tale contains a lot of archaic motifs: Sukhenko, going on a 
fight with The Serpent, gives his brothers charming gloves («If the foam comes from my gloves - rejoice, and if the blood, then run for yourself»); he has the ability to turn into animals («he turned into a cat and ran»); the Serpent's wife commands her daughters, that pursue the heroes after the death of the Serpent, to turn into a «silver and golden well», «silver and golden apple», «blackberry with silver and golden flowers», but Suchenko unravels their design and rescues the brothers; the old Serpent's wife takes the form of a chthonic monster - «as the old Serpent's wife flies: one of her lips is under the clouds and the other one draws on the ground»; in the battle with the Serpent's wife Suchenko receives the help from the blacksmiths Kuzma and Demyan, according to popular beliefs, blacksmithing is a magical matter. The fairy tale «About Sukhenko-warrior» is interesting because it intertwines the motifs of two different initiations: if the first part of the fairy tale is the battle of a hero with the Serpent and escape from it (perceived as a process of initiation of maturation), the second describes how he goes «from Tsaronos to Tsarolos's daughter to marry». Music, Cold, Ryadninka, The one who eats and does not eat, The one who drinks and does not drink, Koromyslo, Vernydub and Vernygora are other characters with extraordinary powers, which he met along the way and who help him to complete the King's tasks [12; Pp. 143-145].

A distinctive difference between the Ukrainian and Japanese fairy tales, which includes the auxiliaries of satellites of the protagonist, is that the relationship between the main character and the heroes who help and travel with him in Ukrainian fairy tales are built on the basis of equality, while in the Japanese - on the model of «master-servant». In fact, the main feature of Ukrainian fairy tales is brotherhood. This is clearly expressed in the tale «About Sukhenko-warrior». In the tale « About The Boy Who Freed his Mother from the Captivity of the Poganyn».

In the Japanese fairy tale Tarot goes on a journey to be famous for feats. Here, the plot is also complicated by his encounter with other heroes: Taro-Boulder and TaroChapel. Each of the meetings turns into a competition for the determining of the most powerful man: «Do not interfere with me with your stones!» - said Taro and pushed the stones to the side with one stroke of a rod. The stranger became angry: «How did you dare?» Do you know that I, Tarot-Boulder, is the strongest in Japan?»he replied and swung at the Taro with a stick. But Taro was faster: he waved his rod and the stranger flew like a ball into the sky. Tarot looked up, waiting a bit, watching - Tarot-Boulder was already on the ground. «Well, have you understood who you are dealing with?» - «I understood. Please take me as your servant!» - Taro-Boulder pleaded with his hands together. Tarot made him his servant and they went further together» [30; P. 317].

Neither Tarot-Boulder nor Tarot-Chapel in the story of a fairy tale plays a significant role: both of them swallowed by the monster right away. However, this is a characteristic feature of the Japanese fairy tale as a feature of the national mentality: in this way again the strength of the protagonist and his status are emphasized - after all, the servant can not be more courageous and stronger than his master. In a number of Ukrainian fairy tales, this motif is also present (for example, the Pokotigoroshko's broth- ers failed to defeat the Serpent), but he carries a different function and does not acquire such a sharp expressiveness.

The next key difference between Ukrainian and Japanese fairy tales is the depiction of the battle. If the Tarot simply «waved a stick and hit the monster in its stomach» [30; P. 319], from what it perishes, then the battle between the Ukrainian Dragon/Serpent and the main hero takes place according to a predefined formula: first, the mutual «Will we fight, or tolerate?» - «You think that I would ever tolerate a bad creature and give up? Let's fight!» [12; P. 139]; They have three «stages» of the battle: the first stage is that they fight with an equal strenth; than follows the second stage of the fighting; finally, during the third stage the hero cuts off all the Serpent's heads. Japanese fairy tales do not have such a pattern.

It is also worth noting yet another common feature of Ukrainian and Japanese «heroic» fairy tales: it is often necessary to eat a certain dish for the hero to obtain the extraordinary power. Pokotigoroshko must eat the greatest wild boar, oxen and sheep which belong to the shepherds whom he had met - only then can he rescue his sister and brothers from the Serpent [12; Pp. 20-21]. Momotaro from the Japanese fairy tale, along with his magical assistants pheasant, monkey and dog (the representatives of the «three worlds») easily fight the monsters, because they ate the best Japanese cakes from wheat, so the strength was «added» to them a thousand times more [18; P. 33].

Quite often in the tales of Japan the antagonists are characters of the national demonology - yokai. In the fairy tale «Mountain pears» one of the Japanese water yokai is the - Nushi (沼 (ぬま)の主 (ぬし), Numa no Nushi). Fairy tales and legends about it can be found in the most distant areas of Japan, especially mountainous and wooded areas. In them, it is depicted as a terrible and insidious spirit - the owner of impenetrable waters, who live in deserted ponds, swampy terrain, wilderness, in the distant, hidden under the shade of large trees of lakes. It was believed that Nushi is a giant spider or a serpent that can accept a human face. There was a belief that all spiders after the sunset become werewolves and receive demonic power. Therefore, meeting them in the dark is dangerous. It was also believed that, «being near the impenetrable waters, one can not stands so that the shadow falls on the water; otherwise, at the same moment, the Nushi would sow up and pull its victim into a depth [28].

Three brothers - Taro, Jiro and Saburo - one by anothers went to search for the mountain pears for their sick mother. However, the two eldest did not listen to the advice given to them by their old granny: «The road is divided into three paths. At the beginning of each one, bamboo grows. If the bamboo begin to rustle: «Come here, go», «Do not go». You go along the path where bamboo rusts «Come here, go» [22; P. 98]. They are stopped by a raven, «an empty pumpkin», but it does not help - Nushi swallows them.

To the youngest of the brothers, Saburo, grandma gives a sharp sword. In the fairy tale, the hero's assistants are pears that sing a song that is a hint of choosing the right road: «On the east side, take care, waiting for danger; and not western, you are afraid, the dark whirlpool waits for 
you. And in the north just a shadow will fall on the water. On the south side, pears you collect» [22; P. 99].

When Saburo listened to the song of pears, he secretly ripped many fruits, but when he began to climb off a tree, he reached for the branch just above the whirlpool, and his shadow fell reflected on the water. «The Lord of the waters saw him and when it was ready to swallow the young man, Saburo took out a sword from the capes, given him by the old woman, and made a strong hit. He murdered the monster «...» and from its open belly showed up his brothers Taro and Jiro, both pale, but alive. He then scooped the water with a red cup and gave to drink it to the brothers. And again they became healthy and strong» [22; P. 100]. Attention is drawn to the presence in Japanese fairy tales, as in the Ukrainian ones, of the notion of magical living water. In addition, the image of the old wise grandmother (grandfather) as an assistant to the protagonist is also characteristic of Ukrainian fairy tales. For example, in the tale "About The Boy Who Freed his Mother from the Captivity of the Poganyn», the oldest, 109-years-old grandmother told the boy that his mother was alive, where to look for her, and told how to get a magic horse that would help him [12; P. 343].

Conclusions. 1. The motifs of the fight of the heroes with evil forces (antagonist) and the victory of the light side (protagonist) are common for both Japanese and Ukrainian fairytales. However, in the Ukrainian tradition the fairy tales with the characters who fight the Serpent/Dragon are the most numerous group of heroic fairy tales. In Japanese folklore, such fairy tales are less common.

2. In Japanese fairy tales, the antagonists of the main hero are often the various characters of the Japanese demonology: demons Oni, the lake spirit and Lord Nushi, and others.

3. In Japanese folklore, there is the unique character of the Dragon God - a sea ruler. The character has a positive connotation and cannot be found in Ukrainian folklore.

4. In the texts of fairy tales, where there are motifs of fighting the Serpent, the characters of the protagonist and the Dragon/Serpent-antagonist, the Dragon/Serpent in the Japanese fairy tale have the same traits as in the Ukrainian and Western-European traditions, but at the same time, the unique national specifics. As in the Ukrainian fairy tales, it acts only in its territory. However, unlike the Ukrainian one, where in later texts the Dragon/Serpent gets anthropomorphic features and features of the peasant environment (sitting on the porch of the house, drinking tea with guests, and others), the Japanese Dragon/Serpent not only has zoomorphic features, which makes it closer to the Western European tradition, its appearance is a symbiosis of the different animals parts: a snake's neck, a horse's head, bull's ears, blue fish scales, and others. This symbiosis is inherent in the Asian tradition.

5. Like in the Ukrainian tradition, unlike other ethnic groups, the Dragon/Serpent of a Japanese fairy tale has signs of the Middle Ages Knights: it gives the hero the right to start the battle, offers him to hit first and offers him a rest during the battle.

6. Functions of the Dragon/Serpent in the Japanese fairy tales are different from the functions of similar characters in the fairy tale traditions of other ethnic groups: if in the Ukrainian fairy tales the Dragon/Serpent kidnaps young females (the reflection of the ancient rituals of the sacrifice to the totem god) and in Western Europe, as well as in the Arabian fairy tales, it protects the material treasures which are hidden in the depths of the mountains, caves (the ancient notions of the world, the bottom of the axis of the world), And in the Japanese fairy tales treasures which are protected by the Dragon/Serpent are hidden on the top of the mountain (the symbol of the axis of the world, the upper level). These treasures are spiritual, such as honesty, justice, happiness, goodness for the whole Japanese nation, which shows the unique Japanese national feature of the character of a Dragon/Serpent.

7. The another unique motif in Japanese fairy tales which is not found in the fairy tales of other ethnic groups is outlined. In the fairy tales of other ethnic groups' folklore traditions, the motif of the help is realized through the paradigm of the characters of magic assistants but the battle takes place only between the main antagonist and protagonist.

8. In the Ukrainian fairy tales about the heroes with extraordinary power the main «villain» is the Serpent (in the anthropomorphic or zoomorphic form); less often it is a Demon - a later character, which appeared under the influence of Christianity, but has «typical features» of the Serpent.

9. The next key difference between Ukrainian and Japanese fairy tales is the depiction of the battle. If the Tarot simply «waved a stick and hit the monster in its stomach» [30; P. 319], from what it perishes, then the battle between the Ukrainian Dragon/Serpent and the main hero takes place according to a predefined formula.
1. 日本昔話集成 (1957) Retrieved from: http://kotobank.jp/word/\%E3\%80\%8A\%E6\%97\%A5\%E6\%9 C\%AC\%E6\%98\%94\%E8\%A9\%B1\%Е9\%9B\%86\%Е6\%88 $\% 90 \%$ E3\%80\%8B (accessed October 21, 2019). p. 272-275

2. Asadchyh, O.V., Dzyub, I.P, Kataoka K. (2012). Folk Epic «The Land of the Sunrise»: Teach. manual. $184 \mathrm{p}$.

3. Bane, T. (2014). Encyclopedia of Demons in World Religions and Cultures. McFarland. 416 p. ISBN 0786488948.

4. Borghouts, J. F. (1973). The Evil Eye of Apopis. The Journal of Egyptian Archaeology. 114-115 p.

5. Dalley, S. (1987). Myths from Mesopotamia. Oxford University Press. 368 p. p. 329.

6. Davydiuk, V. (2005) Pervisna mifolohiia ukrainskoho folkloru/ (The original mythology of Ukrainian folklore). Lutsk: Volyn Regional Printing House. 310 p.

\section{RENCES}

7. Dunaievska, L. (2009) Ukrainska narodna proza (lehenda, kazka): evoliutsiia epichnykh tradytsii/(Ukrainian folk prose (legend, fairy tale): the evolution of epic traditions). Kyiv University Publishing and Printing Center. 304 p.

8. Eire, C. (2010). A very brief history of eternity. Princeton University Press. ISBN 9780691133577. 288 p. p. 29.

9. Ellis, J. (2009). Forbidden Rites: Your Complete Introduction to Traditional Witchcraft. O Books. $645 \mathrm{p}$. ISBN 9781846941382. p. 480.

10. Fontenrose, J. E. (1959) Python: A Study of Delphic Myth and Its Origins. University of California Press. 616 p. p. 134.

11. Frazer, J. G. (1918-1919). Folk-Lore in the Old Testament. Studies in Comparative Religion Legend and Law in Three Volumes. Volume 1. London: MacMillan \& Co., Ltd. 570 p. Retrieved from https://biblicalstudies.org.uk/pdf/e- 
books/frazer/folk-lore_in_the_ot_frazer_vol01.pdf (accessed October 21, 2019). pp. 48-52.

12. From the living source: Ukrainian folk tales in the records and publications of Ukrainian writers. Arrangements, introduction article and notes by Dunaievska, L. (1990). Kiev: Soviet school. $512 \mathrm{p}$.

13. Garrison, E. G. (1998). History of Engineering and Technology: Artful Methods. CRC Press. $368 \mathrm{p}$ ISBN 9780849398100

14. Gauding, M. (2009) The Signs and Symbols Bible: The Definitive Guide to Mysterious Markings. Sterling Publishing Company, Inc. 400 p. ISBN 9781402770043.

15. Gopal, M. (1990). K.S. Gautam (ed.). India through the ages. Publication Division, Ministry of Information and Broadcasting, Government of India. 244 p.

16. Japanese fairy tales «The Fan of youth». Translated from Japanese by Feldman, N. (2005). Moscow: Fortune. 206 p.

17. Japanese fairy tales. Translated from Japanese by Markova, V. (2014) Moscow: Olma Media Group. 304 p.

18. Japanese Literature: Reader. Volume I (VII-XIII centuries). Organized and translated from Japanese by Bondarenko, I., Osadcha, Yu. (2010). Kyiv: Publishing House Dmitry Burago. $562 \mathrm{p}$.

19. Kleisberg, G. (2010). Lost Knowledge of the Ancients: A Graham Hancock Reader. Inner Traditions/Bear \& Co. 256 p. ISBN 9781591431176. p. 27.

20. Lintura, P. (1979). Tales of one villag. Uzhgorod: «Carpathians». $367 \mathrm{p}$.

21. Marcus, G. J. (Oct., 1955). Hafvilla: A Note on Norse Navigation Speculum, Vol. 30, No. 4. pp. 601-605, Published by: Medieval Academy of America. Retrieved from https://www.jstor.org/stable/2849616_(accessed October 21, 2019).

22. Markova, V. (2005) Legends and Tales of Ancient Japan («Bibliotheca mythologica» Series). Ekaterinburg: UFactoria. $512 \mathrm{p}$.

23. Meletinsky, E. (2005) The Hero of the Fairy Tale: the Origin of the Image. Moscow - St. Petersburg: Academy of Cultural Studies, Tradition. $240 \mathrm{p}$.

24. Mori, K. (1980). Yanagita Kunio: An Interpretive Study. Japanese Journal of Religious Studies 7/2-3: pp. 83-115. Re- trieved from http://nirc.nanzan-u.ac.jp/nfile/2210 (accessed October 21, 2019).

25. Novikov, N. (1974). Images of the East Slavic fairy tale. L.: Science. $255 \mathrm{p}$.

26. Ogden, D. (2013). Drakon: Dragon Myth and Serpent Cult in the Ancient Greek and Roman Worlds. Oxford, England: Oxford University Press. ISBN 9780199557325 Retrieved from https://books.google.com.ua/books?id=FQ2pAK9luwkC\&pri $\mathrm{ntsec}=$ frontcover \&dq=ancient+Greek+dragons\&redir_esc=y $\& \mathrm{hl}=\mathrm{uk} \# \mathrm{v}=$ onepage $\& \mathrm{q}=$ ancient $\% 20 \mathrm{Greek} \% 20$ dragons $\& \mathrm{f}=\mathrm{fal}$ se (accessed October 21, 2019).

27. Propp, V. (2000). The historical roots of the fairy tale. M.: Labyrinth. $\quad 336 \mathrm{p}$. Retrieved from http://biblio.imli.ru/images/abook/folklor/Propp_V.YA._Istor icheskie_korni_volshebnoj_skazki._2000.pdf_(accessed October 21, 2019).

28. Sadokova A. R. (1998) Do not say the name to a demon... (about insidious watermen, hapless monsters and bogeymen, whom no one has ever seen). Moscow. № 21-22. Retrieved from https://istina.msu.ru/publications/article/23169642/ (accessed October 21, 2019).

29. Sadokova, A.R. (2000) Mythology of the Japan nation: Literary and oral versions./dissertation for the degree of Ph.Dissertation in specialties 10.01.06, 10.01.09. Moscow. $449 \mathrm{p}$.

30. Sydorenko, I, Romanets, V. (1998). Fairy tales of ethnic groups. Kyiv: Veselka. 447 p.

31. The Types of the Folktale: A Classification and Bibliography. Antti Aarne's «Verzeichnis der Marchentypen» (FFC № 3) translated and enlarged by Stith Thompson. (1961). Second revision. Helsinki: Academia Scientarum Fennica, Fiction. 588 p.

32. Tylor, E. B. (1871). Researches Into the Development of Mythology, Philosophy, Religion, Art, and Custom: Murray, J. Volume 1. p. 426 p. pp. 266-268. Retrieved from https://books.google.com.ua/books?id=AucLAAAAIAAJ\&pr intsec $=$ frontcover\&hl=uk\&source $=$ gbs_ge_summary_r\&cad $=$ $0 \# \mathrm{v}=$ onepage $\& \mathrm{q}=$ snake $\& \mathrm{f}=$ false $\quad$ (accessed October 21, 2019).

33. Yanagita, K. (1954). Japanese Folk Tales. Tokyo News Service. 299 p. 